\title{
Integrating Agriculture and Ecosystems to Find Suitable Adaptations to Climate Change
}

\author{
Anastasia W. Thayer ${ }^{1, *,+}$, Aurora Vargas ${ }^{1, \dagger}{ }^{+}$Adrian A. Castellanos ${ }^{2,+} \oplus$, Charles W. Lafon ${ }^{3}$, \\ Bruce A. McCarl ${ }^{1}$, Daniel L. Roelke ${ }^{4}\left(\mathbb{D}\right.$, Kirk O. Winemiller ${ }^{2}$ and Thomas E. Lacher ${ }^{2,5} \mathbb{D}$ \\ 1 Department of Agricultural Economics, Texas A\&M University, College Station, TX 77843, USA; \\ avarga5@tamu.edu (A.V.); mccarl@tamu.edu (B.A.M.) \\ 2 Department of Wildlife and Fisheries Sciences, Texas A\&M University, College Station, TX 77843, USA; \\ acastellanos@tamu.edu (A.A.C.); k-winemiller@tamu.edu (K.O.W.); tlacher@tamu.edu (T.E.L.) \\ 3 Department of Geography, Texas A\&M University, College Station, TX 77843, USA; clafon@geog.tamu.edu \\ 4 Department of Marine Biology, Texas A\&M University, Galveston, TX 77554, USA; droelke@tamu.edu \\ 5 Center for Coffee Research and Education, Texas A\&M University, College Station, TX 77843, USA \\ * Correspondence: anastasia.thayer@usu.edu; Tel.: +1-4357970793 \\ + Seniority of authorship shared by first three authors.
}

Received: 9 December 2019; Accepted: 8 January 2020; Published: 9 January 2020

\begin{abstract}
Climate change is altering agricultural production and ecosystems around the world. Future projections indicate that additional change is expected in the coming decades, forcing individuals and communities to respond and adapt. Current research efforts typically examine climate change effects and possible adaptations but fail to integrate agriculture and ecosystems. This failure to jointly consider these systems and associated externalities may underestimate climate change impacts or cause adaptation implementation surprises, such as causing adaptation status of some groups or ecosystems to be worsened. This work describes and motivates reasons why ecosystems and agriculture adaptation require an integrated analytical approach. Synthesis of current literature and examples from Texas are used to explain concepts and current challenges. Texas is chosen because of its high agricultural output that is produced in close interrelationship with the surrounding semi-arid ecosystem. We conclude that future effect and adaptation analyses would be wise to jointly consider ecosystems and agriculture. Existing paradigms and useful methodology can be transplanted from the sustainable agriculture and ecosystem service literature to explore alternatives for climate adaptation and incentivization of private agriculturalists and consumers. Researchers are encouraged to adopt integrated modeling as a means to avoid implementation challenges and surprises when formulating and implementing adaptation.
\end{abstract}

Keywords: climate change; adaptation; agriculture; ecosystems; externalities

\section{Introduction}

Since the first World Climate Conference in 1979, researchers have been able to document and quantify the effects of anthropogenic climate change on physical climate, human, and natural systems [1]. Due to the economic importance of agriculture and strong ties to ecoregion diversity [2], plus the emergence of dramatic, recent climate change [3], Texas is an ideal region in which to assess the effects of climate change across natural and managed systems. With large parts of Texas being classified as semi-arid, the warmer and more arid regional shifts caused by climate change will be especially critical in long term decision making and in developing adaptation strategies. Over the last 20 years, temperatures across Texas have increased by $0.5-1.5^{\circ} \mathrm{C}$ [4]. Precipitation patterns statewide have shifted, with statewide precipitation in the last century exhibiting increased rainfall in the east 
and decreased rainfall in the west [5]. At the same time, extreme weather events such as heavy rains, extreme droughts, tropical storms, and hurricanes, are becoming more common [4]. As a result, individuals and landscapes are responding. Winter wheat is no longer flowering at the same time as it did historically [6]. There have been marked declines in the quality and amount of habitat for birds [6,7], mussels [8], and butterflies [9], among many other species. Changes in temperature, precipitation, atmospheric carbon dioxide concentrations, and extreme event frequency/severity are impacting the distribution and function of agriculture and ecosystems in Texas.

As global carbon and other greenhouse gas emissions continue to increase, future model projections suggest that additional climate alterations are inevitable. Furthermore, even if global emissions were to return to pre-industrial levels the atmosphere would stay at current concentrations for many decades, with global surface temperatures continuing to increase and physical climate effects persisting well beyond 2100 [10]. Under a scenario where global emissions continue to increase through 2100 (under Representative Concentration Pathway 8.5) as they have for the last 100 years or more, it is expected that temperatures will increase across Texas and the Great Plains of the United States with 2070-2099 minimum temperatures approximately $6-8{ }^{\circ} \mathrm{C}$ higher and maximum temperatures $5-7^{\circ} \mathrm{C}$ higher relative to 1971-1999 [11]. Precipitation patterns are also expected to become more extreme with the number of consecutive dry days increasing in 2070-2099 by 0-18\% and maximum one-day precipitation totals increasing by 12-18\% again compared to 1971-1999 [11]. Furthermore, in Texas, the number of days over $38^{\circ} \mathrm{C}$ is expected to increase as is the number of warm nights [12]. Future conditions are expected to lead to even more agricultural and ecosystems shifts, disruptions, and production variability.

Given the already observable current impacts of climate change and projections of inevitable larger impacts, understanding how systems will respond and adapt is critical to maintain function. Systems that rely on climate characteristics and atmospheric carbon dioxide are especially vulnerable. The rapid rate of change poses unprecedented threats [13]. This is especially true for agriculture and ecosystems as they are fundamentally reliant on climate and carbon dioxide for productivity and their mix of available products/services. Interdependencies in resource usage, competition for space, and the movement of water, nutrients, and species among agriculture and ecosystems lead in effect to a unified interdependent system facing common drivers and constraints.

To date, research efforts on climate change effects and possible adaptations have been largely independent, concentrating on either agriculture or non-agricultural ecosystems but not both simultaneously. Failure to jointly address the effects and inform on the consequences of adaptations generates only a partial view of vulnerabilities and the implications of possible adaptations. This work argues that evaluations at the intersection of agriculture and ecosystems allow for analysis of synergies, feedbacks, and tradeoffs. Analyses that integrate impacts on and responses by both human and natural systems create a more robust, complex, and holistic evaluation of climate-change-related threats and possible adaptive decision making.

Additionally, global analyses overlook important regional characteristics and peculiarities that color vulnerabilities and adaptation implications. Here, we draw together evidence on how climate change and possible adaptations affect agriculture and ecosystems both individually and in interaction. We ask what the research and policy implications of analyses that ignore linkages between agriculture and ecosystems when exploring climate change effects and adaptation are. We find that a joint systems analysis is more informative as an input to ecosystem and agricultural management. In particular, in the Texas semi-arid setting we (1) briefly review the literature on the main impacts and vulnerabilities imposed on agriculture and ecosystems, (2) describe the interdependency of agriculture and ecosystems and the need for integrated climate change research, (3) discuss current and future adaptation possibilities and appraisal approaches, (4) introduce challenges for research in general and in the Texas-specific setting, and (5) argue the need for integrated research and modeling when understanding impacts of a climate-evolved future and the possibility of adaptation action. 


\section{Literature Review}

Most climate change impacts research has considered agriculture and ecosystems to be independent of one another [14-17]. Few studies attempt to analyze the joint impact of adaptations or propose potential adaptation strategies that would reduce the negative impact of climate change across both systems. Recognizing the state of knowledge in each system, methodology used to date, and remaining research gaps would help identify mutually beneficial research needs and synergies. It would also contribute to an understanding of how addressing the systems jointly can help identify tradeoffs and possibilities for mutually beneficial outcomes. Here, we review the existing literature related to climate change impacts for agricultural crops, livestock, and food production along with general impacts on ecosystems, vegetation, and aquatic systems. A summary of climate change impacts on agriculture and ecosystems is shown in Table 1 and below we present a discussion for each system.

\subsection{Agricultural Studies}

Climate change is expected to have differing effects on cropping systems globally due to regionally specific physical conditions as well as differing mixes of crop and livestock types. For some crops in some regions, climate change has reduced current yields and is expected to reduce long-term agricultural productivity [18]. Agricultural research into climate change effects on crops has benefitted from observationally rich and geographically detailed datasets [19]. Studies can also take advantage of long-term, highly controlled, multi-site, manipulatable experimental studies [20,21]. The current extent of climate change has been shown to shift crop geographic distributions toward higher latitudes and elevations [19,22]. Studies have demonstrated that future crop productivity is expected to be limited by increased variability in weather and physical growing conditions [23], differentially impacted by carbon dioxide concentrations [24,25], and limited on a regional basis by dwindling water availability [26]. Other effects such as slowing technological progress $[25,27]$ and increased pest damages and pesticide costs [28] are all expected to further alter productivity and costs. In Texas, a climate that is becoming warmer and drier with a greater probability of extreme events is expected to lead to declining yields for crops such as cotton [29] with greater variability due to extreme weather events [30]. Furthermore, lower soil moisture [31] is expected to increase aquifer pumping, in turn increasing drawdown and water stress. Finally, increased pest, disease, and invasive species frequency is expected to raise management costs [28,32].

Livestock, especially cattle, are expected to be directly impacted by climate change and increased heat stress but also indirectly though impacts on forage and feed grain yield reductions [33]. In the US, direct livestock losses due to heat stress are estimated to be $\$ 2.4$ billion annually from decreased reproduction rates, feed consumption, and feed efficiency affecting animal growth rates [34-37]. Lower forage and feed quality are also expected [38] as increased temperatures negatively affect growth conditions and nutrient availability [39]. In Texas, warmer and drier conditions are expected to reduce total livestock production through lower stocking rates and reduced per animal production. Lower grassland growth rates and nutritional quality will force increased supplemental feeding and costs [40]. Total grassland productivity is also expected to decrease with the expansion of woody plants [40], although movements of land from cropping are expected to increase grass land quantity [41]. Expansion and greater incidence of disease, ectoparasites, and other pests are expected to decrease animal productivity $[30,40,41]$.

The impact of climate change on agricultural systems also has implications for land prices, transportation, storage, food safety, labor, and consumer prices. These critical processes within the supply chain for agricultural products are expected to be affected with alterations occurring at every stage of production, including input sourcing, packaging, and processing [42]. It has been suggested that additional precautions might have to be considered to maintain food safety and reduce spoilage, such as increased storage and cooling facilities [43,44]. Relevant to Texas, shifting US production capacity is expected to change routes and methods used to transport agricultural products [45]. On a larger scale, global shifts in production capacity are anticipated which will alter comparative 
advantages, international trading routes, and partnerships [42]. Agricultural prices will also be impacted. However, determining the direction, magnitude, and associated changes to producer and consumer welfare as a result is complicated [46-48]. For example, price changes may impact urban versus rural consumers or other sub-groups within the same market differently [48]. Agricultural labor supply is also predicted to be impacted, and, with it, rural incomes $[49,50]$. Finally, changes in agricultural land values are anticipated as historic land use is expected to shift either due to changes in the agricultural activity utilizing the land, land moving out of agricultural production all together, and/or changing values of land based on water or other resource availability [48].

\subsection{Ecological Studies}

While agricultural scientists have been able to study effects using large public datasets and publicly funded experiments, work on ecosystem effects has proven more difficult. For natural ecosystems there is a lack of widespread data availability. Furthermore, most available data sets focus on one species and/or geographic area with substantial inconsistencies in study-time horizon [51,52]. Nevertheless, consistent impacts and vulnerabilities have been identified.

Foremost, biodiversity is threatened by climate change due to the rising trend and magnitude of change over a short timeline. This impacts all levels of biodiversity, from individual organisms to populations and ecosystems [53]. Extirpation of regional populations and global extinction continue to be the most visible impacts, although establishing the extent of climate change causality remains challenging because species vary in their capacity to adapt [54]. However, in recent years, our ability to model these shifts has improved due to the creation and continued proliferation of biodiversity data repositories (e.g., GBIF) and VertNet, etc.; [55]) and finer scale environmental data (e.g., EarthEnv, SoilGrids, and WorldClim; [56-58]), in addition to improvements in climate model resolution [59].

Climate change has already been found to alter species geographic distribution, phenology, behavior, and patterns of habitat use, with more change expected in the coming decades. Organisms adapt to inhospitable physical climate conditions by shifting, expanding, or contracting their historic ranges $[60,61]$, and for a few species, perishing. Climate-associated range shifts have been observed across a wide geographic and taxonomic scope, including flora in the Himalayas [62] and the western United States [63], birds in New Guinea [64], Amazonian fish [65], and small mammal communities [66], just to name a few. As an example, Parmesan and Yohe [51] sampled 1598 species across multiple taxa, of which $59 \%$ had exhibited changes in their phenology or distribution over the past 20 to 140 years. Furthermore, the presence of novel climate niches and geographic barriers that reduce dispersal and gene flow [67] will likely limit the potential for natural adaptation.

Across Texas, species already are showing dramatic responses to climate change. For example, migration patterns for resident birds have been impacted [68]. Model projections indicate that some rodent species will go extinct and species geographic ranges are expected to shift $54 \%$ or more depending on the extent of climate change [69]. Diseases, invasive species, and pests are expected to change their distribution with ecological consequences, with, for example, tick vectors shifting and likely bringing diseases into new regions, impacting both humans and wildlife [70,71]. This will require more complex eradication and control strategies [72] as tick-borne disease relationships are changed [73]. These are just a few examples of the profound impact on wildlife populations.

Vegetation communities are also responding. Plants are governed by stress and disturbance, and climate-induced changes to these factors will alter vegetation composition, productivity, and distribution [74,75]. Changes in temperature, precipitation, and climatic extremes can increase stress and limit plant growth [76,77]. In Texas and other semi-arid regions, warming-induced increases in evapotranspiration are expected to reduce plant productivity [78,79]. Moreover, as precipitation variability increases, grassland productivity decreases regardless of constant average rainfall [80]. Clearly, climate variability matters when considering damage from climate change. Shifts in disturbance regimes are expected due to changes in the prevalence and distribution of fires, floods, hurricanes, and insect outbreaks, thus forcing communities into altered states [81,82]. These transitions can occur 
rapidly when severe disturbances are combined with increasing stress and they can lead to permanent vegetation community changes $[83,84]$.

Table 1. A summary of climate change impacts on agriculture and ecosystems.

\begin{tabular}{|c|c|c|}
\hline & Climate Impacts on Agriculture & Citations \\
\hline \multirow{5}{*}{ Crops } & Crop mixes and distributions are shifting northward to higher elevation & {$[19,22]$} \\
\hline & $\begin{array}{l}\text { Future crop productivity (1) limited by increased variability in weather and physical growing } \\
\text { conditions, (2) differentially impacted by carbon dioxide concentrations, (3) limited by } \\
\text { dwindling water availability, (4) limited by slowing technological progress, and (5) limited by } \\
\text { increased pesticide costs. }\end{array}$ & [23-28] \\
\hline & $\begin{array}{l}\text { Texas: warmer and drier climate-reduced crop yields and increased losses due to extreme } \\
\text { weather events }\end{array}$ & {$[29,30]$} \\
\hline & Texas: lower soil moisture leading to increased aquifer pumping and water stress & [31] \\
\hline & $\begin{array}{l}\text { Texas: increased frequency of pest, disease, and invasive species which raises crop } \\
\text { management costs }\end{array}$ & {$[28,32]$} \\
\hline \multirow{6}{*}{ Livestock } & Increased heat stress and reduced forage and feed growth & [33] \\
\hline & $\begin{array}{l}\text { Livestock losses from decreased reproduction rates, feed consumption, and feed efficiency } \\
\text { affecting animal growth rates }\end{array}$ & [34-37] \\
\hline & $\begin{array}{l}\text { Lower forage and feed quality due to increased temperatures affecting growth and } \\
\text { nutrient availability }\end{array}$ & {$[38,39]$} \\
\hline & $\begin{array}{l}\text { Texas: lower stocking rates and reduced per animal production due to warmer and } \\
\text { drier conditions }\end{array}$ & [33] \\
\hline & $\begin{array}{l}\text { Texas: increased supplemental feeding due to lower grassland growth rates, quality, and } \\
\text { acreage with the expansion of woody plants }\end{array}$ & [40] \\
\hline & $\begin{array}{l}\text { Texas: decreased animal productivity due to the expansion and greater incidence of disease, } \\
\text { ectoparasites, and other pests }\end{array}$ & {$[30,40,41]$} \\
\hline \multirow{7}{*}{$\begin{array}{l}\text { Supply } \\
\text { Chain }\end{array}$} & Input sourcing, packaging, and processing affected by climate change & [42] \\
\hline & $\begin{array}{l}\text { Additional storage and cooling facilities necessary to maintain food safety and reduce } \\
\text { spoilage from increased temperatures }\end{array}$ & [42-44] \\
\hline & Shifting US production capacity will change transportation routes and methods & [45] \\
\hline & $\begin{array}{l}\text { Altered comparative advantages, international trading routes, partnerships, and trade } \\
\text { agreements due to shifts in production }\end{array}$ & [42] \\
\hline & $\begin{array}{l}\text { Difficulty in determining the direction, magnitude, and associated changes to producer and } \\
\text { consumer welfare }\end{array}$ & [46-48] \\
\hline & Agricultural labor supply is predicted to be impacted, and with it rural incomes & {$[49,50]$} \\
\hline & Changes in agricultural land values as historic land use shifts & [48] \\
\hline & Climate Impacts on Ecosystems & Citations \\
\hline \multirow{7}{*}{ Fauna } & $\begin{array}{l}\text { Biodiversity is threatened due to the trend and magnitude of rapid changes over a } \\
\text { short timeline }\end{array}$ & [53] \\
\hline & $\begin{array}{l}\text { Extirpation due to varied capacity of species to adapt to environmental changes brought about } \\
\text { by climate change }\end{array}$ & [54] \\
\hline & $\begin{array}{l}\text { Organisms respond to inhospitable physical climate conditions by shifting, expanding, or } \\
\text { contracting their historic ranges }\end{array}$ & {$[60,61]$} \\
\hline & $\begin{array}{l}\text { Barriers to dispersal that reduce gene flow in landscapes which limit potential for } \\
\text { natural adaptation }\end{array}$ & [67] \\
\hline & Texas: migration patterns for resident birds have been impacted & [68] \\
\hline & Texas: some rodent species will go extinct and geographic shifts of $54 \%$ or more will occur & [69] \\
\hline & $\begin{array}{l}\text { Texas: tick vectors are shifting and will likely bring diseases into new regions impacting } \\
\text { humans and wildlife, resulting in more complex eradication and control strategies }\end{array}$ & {$[70-73]$} \\
\hline
\end{tabular}


Table 1. Cont.

\begin{tabular}{|c|c|c|}
\hline & Climate Impacts on Agriculture & Citations \\
\hline \multirow{4}{*}{ Flora } & $\begin{array}{l}\text { Altered vegetation composition, productivity, and distribution due to climate-induced stress } \\
\text { and disturbance }\end{array}$ & {$[74,75]$} \\
\hline & $\begin{array}{l}\text { Limited plant growth due to changes in temperature, precipitation, or the incidence of } \\
\text { climatic extremes }\end{array}$ & {$[76,77]$} \\
\hline & Texas: reduced plant productivity due to increasing evapotranspiration & {$[78,79]$} \\
\hline & $\begin{array}{l}\text { Altered prevalence and distribution of fires, floods, hurricanes, and insect outbreaks forces } \\
\text { communities into a stressed state which can lead to permanent changes to vegetation }\end{array}$ & [81-84] \\
\hline \multirow{4}{*}{$\begin{array}{l}\text { Aquatic and } \\
\text { Riparian }\end{array}$} & $\begin{array}{l}\text { Hydrological environment areas that cycle nutrients, maintain water quality, and moderate } \\
\text { lifecycle events such as spawning and recruitment are disrupted by climate changes }\end{array}$ & [85-88] \\
\hline & Dewatered channel segments leading to habitat fragmentation due to reduced flows & {$[86,89]$} \\
\hline & $\begin{array}{l}\text { Texas: disrupted productivity and biodiversity of stressed freshwater inflows due to } \\
\text { human appropriation }\end{array}$ & [90] \\
\hline & Increased algal blooms due to warmer water temperatures and changes in rainfall & {$[91,92]$} \\
\hline
\end{tabular}

Aquatic and riparian systems are also affected. The hydrologic environment adds an additional layer of complexity as it also cycles nutrients, alters water quality [85-87], and moderates lifecycle events such as spawning and recruitment [88]. When rivers and streams in arid and semi-arid regions experience severely reduced flows, channel segments may become dewatered, resulting in habitat fragmentation and threatening the population viability of rare endemic species at scales that often extend well beyond the impacted habitat $[86,89]$. In Texas, freshwater inflows that support coastal ecosystems are expected to come under increasing stress from human appropriation and altered flow levels, and this will further disrupt future productivity and erode native biodiversity [90]. Looking ahead, harmful algal blooms are expected to become an increasing problem [91,92]. As conditions become drier and the magnitude and frequency of freshwater inflows decline, such algal blooms are likely to cause larger fish kills and substantial financial damages.

\subsection{Summary Table}

In Table 1, below, is a summary of the relevant literature from agriculture and ecosystem studies.

\section{Need for an Integrated Approach}

The above material clearly shows that climate change disruptions to temperature, precipitation, and extreme events threaten the health, function, and productivity of agriculture and more generally ecosystems. However, gaps remain in understanding and projecting future impacts, especially since critical interactions between agriculture and ecosystems have largely been ignored. These interactions can include externalities or unintended effects, additional drivers, feedback loops, and tradeoffs. For example, pesticide use is expected to increase as a result of emerging and expanding pest populations [28]. Pesticides impact not only ecosystems where they are applied but also have far reaching effects when they are transported via runoff and infiltration [93,94]. As another example, the interactions between cattle and grassland production and forage quality has not been well integrated into climate change research [41,95]. Warmer and drier climates stress livestock [34] but estimates of damages have not fully considered the additional effects of decreased shade cover and less water availability on rangeland grazing animals. Adaptation to such simultaneous stressors may lead to increased costs, lower productivity, and less revenue [30]. In Texas and other areas with extensive rangeland acreage and cropland under input-intensive agriculture, if synergistic impacts across the ecosystem are not considered, the costs of both projected and realized climate change might be severely underestimated, leading to reduced adaptation action.

An improved understanding of how the systems interact and of the relevant feedbacks need to be developed. Arguably, the most widespread effort to begin to unify agriculture and ecosystems has occurred through monetary valuations of ecosystem services [96-99]. However, this effort falls 
short of holistically incorporating ecosystems and agricultural regimes into a shared conceptualization of climate change effects. Rather, ecosystem valuation is typically reduced to a short-sighted service value or a dynamic financially-discounted contribution over time $[97,99]$. When efforts to evaluate agricultural practices in the presence of ecosystems do take place, the results confirm that ignoring this duality leads to severely biased findings $[100,101]$.

For climate change research, this forces a discussion of the validity of findings on climate change effects and adaptations when one system is analyzed in isolation. Some researchers have identified the need for integrated research and have presented loose guidelines or examples for how to merge studies, disciplines, and research priorities $[100,102]$. However, this is challenging, as the inclusion of increasing degrees of climate change exacerbates existing data limitations, timescale mismatches, geographic scale, unstudied but associated phenomena, and a need for adaptation action to avoid severe consequences. At its base, what is missing from much of current climate change research is an understanding of how rapid change affects the linkages between agriculture and ecosystems and in turn how resilience, future output, and, ultimately, the survival of communities, will be impacted.

Improved understanding could begin with an analysis of ecosystem services including agricultural and other markets as a service and conceptualization of regional interactions. The analysis could start by building off the framework given in Figure 1. Identification and understanding of ecosystem services provided to a particular agricultural system, market, or regional society could rely on existing ecosystem service literature [96-99,102,103]. Given that tradeoffs are known to exist between market services (crops, livestock, and water) and non-market ecosystem services (regulating, supporting, and cultural), attempts are needed to minimize negative impacts or assess best practices. Such examinations will enhance understanding of the problem, thereby avoiding incomplete analysis and flawed results. Identifying tradeoffs of overconsumption will be particularly important. Research efforts that strive to incorporate both systems into an analytic structure will provide more robust and broadly applicable findings and recommendations.

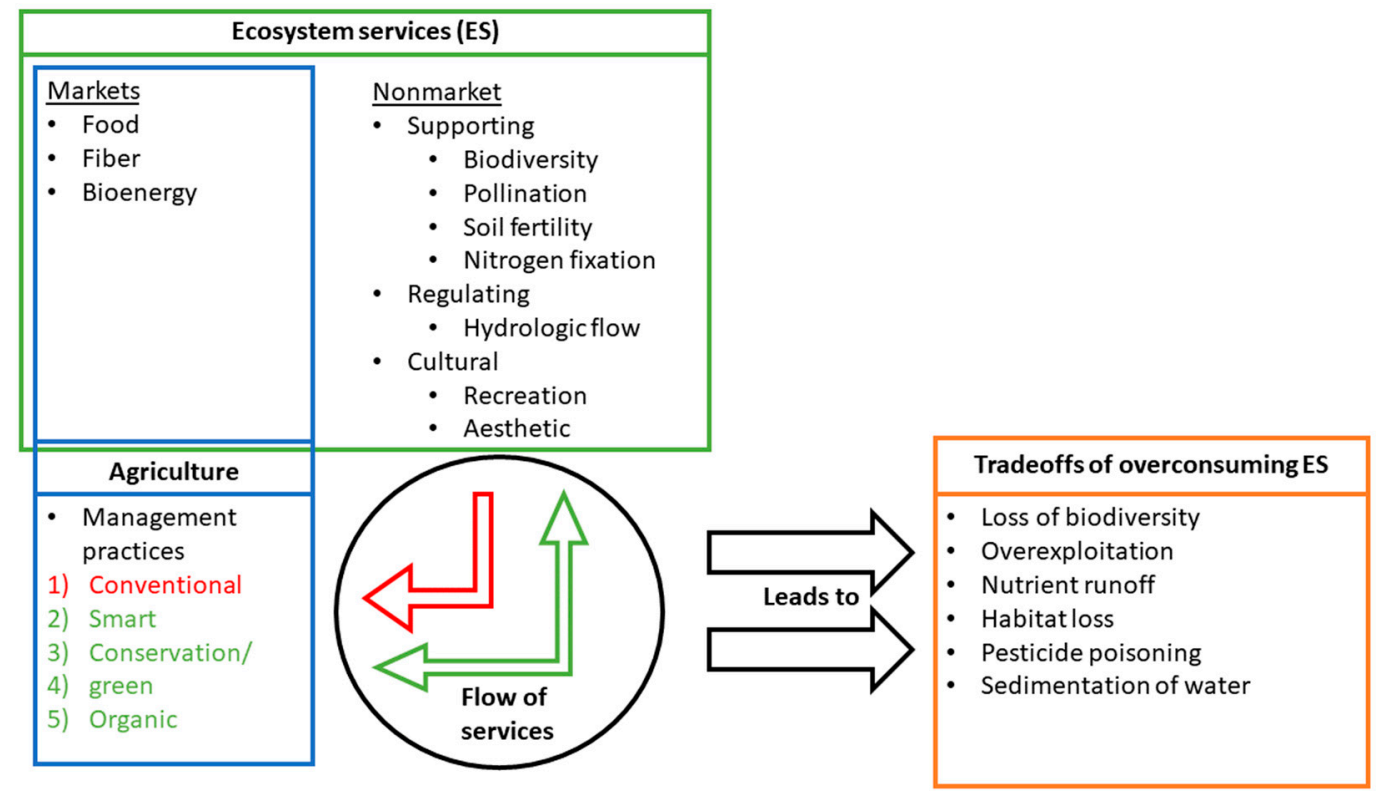

Figure 1. Joint ecosystem and agriculture modeling framework highlighting integrated nature of systems $[96,103]$.

\section{Sustainable Adaptation Challenges and Solutions}

Agriculture and ecosystems are already reacting and responding to climate change by exhibiting altered productivity and species populations. In managed systems individuals, farmers, and researchers are trying to anticipate future changes and adapt in beneficial and cost-effective manners. In unmanaged 
systems, natural adaptation is occurring but not always in desirable ways, and in these cases management intervention is being contemplated often with incomplete knowledge of the consequences. Research efforts projecting effects and evaluating adaptation actions have an even greater incentive to consider an integrated agriculture and ecosystems framework.

Most often, agriculture and ecosystems adapt to climate change effects in response to altered physical climate. A flow chart showing how changes to physical climate can motivate adaptation can be seen in Figure 2. From previous examples, it is clear that changes to physical climate such as increased temperature and altered rainfall can change cereal crop yields [22]. In response, farmers adapt to altered yields by changing crop mixes. Similarly altered species abundance occurs when temperature rainfall or extremes affect regional ecosystems [53,54].

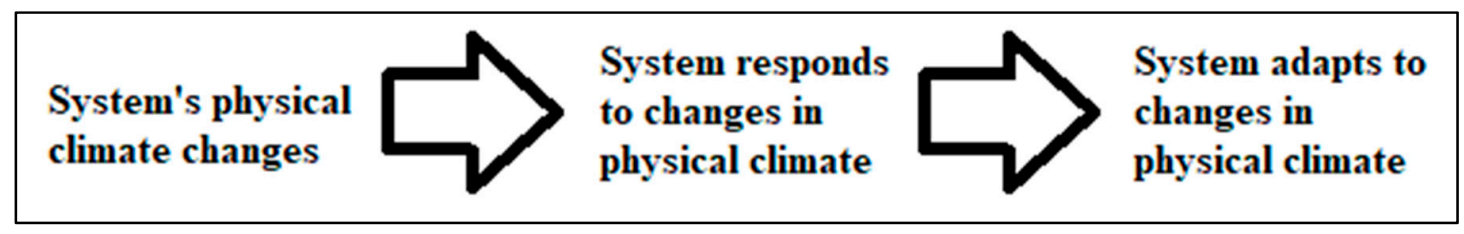

Figure 2. Flow chart describing the primary motivation for systems to adapt to climate change effects.

To date, agricultural systems have largely adapted or considered adapting to climate change through altering management practices and implementing policies that motivate desired behavior or management practices. Much of the published literature on agricultural adaptation uses a large geographic study area and shows that adaptations can lessen the negative impacts of future climate alterations. Within cropping systems, strategies proposed have included earlier planting times, changing crop mixes, and complete shifts of land out of crop into pasture $[19,41,104]$. For livestock, proposals include adopting more heat-tolerant breeds or species, changing stocking rates, providing shade or water, altering pest management, and shifting grazing seasons $[40,105,106]$. Overall, markets and other mechanisms for insurance, such as water rights regimes, water markets, and crop insurance, might also have to evolve, expand, or be redefined under climate change in order to mitigate risk to users [107,108].

As a general economic rule, undertaking adaptation strategies and supporting governmental or institutional efforts will only occur if they are judged superior to current practices [109]. The adaptation strategies listed above seek to minimize risk for individual producers but are usually considered to ignore potential externalities or impacts on the surrounding ecosystem (An externality is simply a market failure where the price of a good does not reflect its value.). In other words, while the chosen adaptations are efficient for a private producer, they may not be efficient for society, or cause substantial ecosystem damages. This commonly happens when looking at environmental goods and services because it is difficult to price all possible benefits and costs, which leads to a poor estimate of value. As seen in Equation (1), only when the marginal private cost (MPC) and marginal social cost (MSC) of an adaptation equals the marginal benefit $(M B)$ do we see an efficient market and an accurately valued good [110], or in this case, a holistic adaptation strategy.

$$
M B=M P C+M S C
$$

When the MSC is not considered, the value of the externality is equal to the value of the MSC, thus making the adaptation inefficient. Inefficient adaptation and maladaptation could cause long-term damages that limit or slow beneficial adaptation to climate change, and, ultimately, increase the damages and costs of climate change $[109,111]$. Studies to date show that some adaptation strategies for agriculture could cause both winners and losers [112]. Thus, failure to incorporate the positive and negative externalities associated with adaptation efforts to a modeling framework in either agriculture or ecosystems has the potential to bias the estimates of benefits and costs causing poor or at least sub-optimal choices to be made. 
Table 2 seeks to provide agricultural and ecosystem examples of potential externalities resulting from adaptations. Column 1 displays the underlying climate change stressor effect that is stimulating adaptation. Columns 2 and 3 show examples of corresponding agricultural management or ecosystem responses. It is useful to note that multiple adaptations can result from one climate change driver. For example, increased drought frequency and duration can motivate farmers to adapt by changing crop mix while also causing ecosystems to adapt, resulting in shifting vegetation mix and water retention.

Table 2. Eight examples of how climate stressors lead to adaptation in agriculture and the corresponding response in ecosystems which can be a positive or negative externality. The opposite case of adaptations in ecosystems and responses in agriculture is then presented.

\begin{tabular}{|c|c|c|}
\hline Climate Stressor & Agricultural Adaptation & Ecosystem Service Externality \\
\hline \multirow{2}{*}{$\begin{array}{l}\text { 1. Increased temperature } \\
\text { and drought }\end{array}$} & $\begin{array}{l}\text { Diversifying livestock } \\
\text { species [113-115] }\end{array}$ & $\begin{array}{l}\text { Altered plant biodiversity and } \\
\text { productivity [116-118] }\end{array}$ \\
\hline & Crop land shift to grazing $[19,41,119]$ & $\begin{array}{l}\text { Increased root production in } \\
\text { upper soil levels and carbon } \\
\text { sequestration }[120,121]\end{array}$ \\
\hline 2. Increased temperature & Heat-tolerant animal breeds [103] & $\begin{array}{c}\text { Dilution of disease } \\
\text { prevalence }[103,122,123]\end{array}$ \\
\hline 3. Increased drought & $\begin{array}{l}\text { Changing crop mix and } \\
\text { rotation }[19,124,125]\end{array}$ & Increased soil quality $[126,127]$ \\
\hline Climate Stressor & Ecosystem Adaptation & Agriculture System Externality \\
\hline $\begin{array}{l}\text { 4. Shifts in temperature and } \\
\text { rainfall patterns }\end{array}$ & $\begin{array}{l}\text { Land vegetative change and habitat } \\
\text { fragmentation }[128,129]\end{array}$ & $\begin{array}{l}\text { Reduction in pollinators and } \\
\text { pollination }[100,130-132]\end{array}$ \\
\hline 5. Increased temperature & Reduced animal body size [133] & $\begin{array}{l}\text { Altered diets and rangeland } \\
\text { economic productivity such as } \\
\text { stocking rates }[41,114,134]\end{array}$ \\
\hline 6. Increased drought & $\begin{array}{l}\text { Shift in vegetation productivity and } \\
\text { water retention }[135,136]\end{array}$ & $\begin{array}{l}\text { Altered water supply and } \\
\text { increased demand for } \\
\text { irrigation }[137,138]\end{array}$ \\
\hline $\begin{array}{l}\text { 7. Increased temperature and } \\
\text { altered rainfall }\end{array}$ & Shifting species distribution $[139,140]$ & $\begin{array}{l}\text { Increased pesticide and herbicide } \\
\text { costs }[28,141,142]\end{array}$ \\
\hline 8. Increased water temperature & Change in phenology $[143,144]$ & Reduced fish survival [145-149] \\
\hline
\end{tabular}

These examples show that adaptation efforts or actions experienced in one system have spillover effects into the other which may impact the function and economic viability of the opposing system. These spillovers increase the uncertainty of outcomes. For researchers and policymakers seeking to make informed adaptation decisions and recommendations, simultaneous human and natural adaptation makes analysis and modeling efforts complex. At the same time, not all observed externalities are negative or are expected to increase damages from climate change. An agricultural adaptation such as switching to more heat-tolerant livestock breeds can introduce less competent hosts for pathogen transmission, diluting disease prevalence in ecosystems. Therefore, to accurately predict, respond to, and make recommendations for adaptation strategies in response to future climate change, a framework that includes both ecosystems and agriculture must be adopted.

\section{Solutions: Improving Modeling Efforts}

Based on the literature, three avenues of approach arise that can assist modeling efforts in merging ecosystems and agriculture systems. These are (1) incorporating alternative practices that can lessen the impact of agriculture on ecosystems, (2) incorporating and advancing modeling of ecosystem services and the way they are affected by agricultural activity, and (3) modeling means of providing economic incentives to encourage adoption of conservation or environmental policies.

Practices exist that can be adopted to reduce agricultural impacts on surrounding ecosystems, as shown by the long US history with soil conservation [150]. There is a large body of literature that 
champions conservation agriculture practices such as reduced/no tillage, retention of crop residues, and altered crop rotation that benefit ecosystem services regulation and provisioning, via expanded carbon sequestration, reduced erosion, and improved soil health [151,152]. Other studies support expanding organic agriculture, which has been shown to reduce off-farm impacts while preserving ecosystem services [103]. However, while these strategies reduce agricultural impacts to ecosystems, more research is needed to optimize management practices so that organic yields can consistently meet or exceed the yields of conventional agriculture since population growth is increasing food demand [153]. Additionally, precision agriculture and climate smart agriculture might also offer a solution, as they rely on optimizing current conventional agricultural techniques and responding to climate change at a more localized level [154-157]. The benefit of these approaches is that they inherently have characteristics which benefit the environment. Continued research and efforts toward incorporating positive environmental externalities into production agriculture decision-making above could present alternative ways to reframe the current narrative to benefit health of both agriculture and ecosystems.

Ecosystem service analysis and modeling methodologies present potential solutions for integrating ecosystems and agriculture. Non-market valuation of ecosystem services determines a value for a particular facet of the ecosystem which benefits humans and provides a quantitative measurement for use in adaptation strategy and associated policy analysis [98]. This approach can be useful for valuing ecosystems and placing them on an equal footing with market transactions. Tools such as the Integrated Valuation of Ecosystem Services and Tradeoffs (InVEST) models help give a quantitative value to ecosystem services in an easy, open-source platform which can then be used to look at land-use change or other scenarios [97]. Many of these modeling efforts will rely on ambitious data collecting efforts such as National Ecological Observatory Network (NEON), a 30-year long-term research project designed to capture a wide range of ecosystem process indicators [158]. These data can then be integrated with output from other systems to incorporate ecosystems, their processes, and how they change over time into decision analysis [159]. More recently, many of the machine learning techniques typically used in species distribution modeling [160] are being used to model biodiversity [82], agricultural suitability [161], and crop mix shifts [162]. As the use of these methods spreads, they will be able to help characterize the contributions and sensitivities of ecosystems relevant to agriculture. Creating causal networks and truly assimilating ecosystems and agriculture could benefit from ecosystem service valuation research and additional long-term ecosystem monitoring databases.

Finally, policies that incentivize private landowner environmental efforts could aid in the public's realized benefits from healthier ecosystems. Also, monitoring the results of such programs would increase understanding of how ecosystems and agriculture interact. In Texas, specifically, most of the land is privately owned and programs such as Texas Ecological Laboratories ("Texas Ecolab") can facilitate connections between researchers and landowners. Such an exercise generates data while advancing environmental goals such as conservation and the conduct of research that improves state interests $[163,164]$. It also economically rewards cooperating landowners for their efforts [165]. Fostering partnerships with private landowners is especially beneficial, as oftentimes there is distrust of government entities [166] that hampers conservation or research efforts [167].

\section{Conclusions}

Future impacts of climate change are inevitable, stimulating ecosystem and agriculture impacts and responses. Understanding how ecosystems and agriculture are inherently linked and projecting climate change consequences, and then using this knowledge to inform adaptation actions has the potential to improve policy and lower social/environmental impacts. Moreover, such an understanding will further protect against inefficient and even detrimental adaptations that cause long-term disruptions. Developing an integrated framework that jointly considers both agriculture and ecosystems enhances our knowledge of the inherent tapestry of occurring interactions. Understanding these interactions 
will help maintain and enhance system resiliency necessary to produce food and human livelihoods while maintaining a productive, high-quality environment.

While an integrated ecosystem and agricultural framework is recommended, other issues remain that will challenge our ability to adapt to climate change in a way that minimizes damages for future generations as well as ecosystems. Firstly, large-scale studies and solutions must be paired with local and regional analysis, interpretation, and flexible implementation to avoid missing localized phenomena $[30,40,168,169]$. Action to integrate agriculture and ecosystems will reveal knowledge gaps related to externalities, feedbacks, and dynamics within and between systems. Secondly, while this work motivates the need for an integrated research framework, we could not find a specific example of where an integrated model proved superior to disjoint efforts. Thirdly, while initially difficult to overcome, increased monitoring and identification of critical data needs will contribute to resolving these challenges. Future research could address identifying and quantifying cause and effect relationships among systems and some research efforts could focus on case studies showing the added benefit of additional data and integrated analyses. Fourthly, funding is also somewhat compartmentalized to individual areas and the development of broader funding opportunities to support this research is needed.

Overall, while an integrated ecosystem and agricultural framework will not solve all climate change challenges, it might help remove some of the uncertainty [170], balance conflicting objectives, and present more nuanced solutions to a complex problem.

Author Contributions: Conceptualization was carried out by A.W.T., A.V., and A.A.C., as well as T.L. and B.A.M.; methodology, same as previous; formal analysis was completed by A.W.T., A.V., and A.A.C.; investigation was formulated by all authors; writing-original draft preparation was carried out by A.W.T. with contributions from A.V. and A.A.C.; review and editing were performed by all authors with substantial contributions by A.W.T., A.V., A.A.C, T.E.L., and B.A.M.; supervision, T.E.L. and B.A.M.; project administration, T.E.L.; funding acquisition, T.E.L. and B.A.M. All authors have read and agreed to the published version of the manuscript.

Funding: This research was funded by the Texas A\&M Grand Challenges Proposal Competition "Building Climate Resilience: Seeking Sustainable Solutions for Water, Agriculture and Biodiversity in Arid Regions".

Acknowledgments: The authors would like to thank the contributions of Professor David Briske as well as participants and conference speakers at the events related to the Texas A\&M Grand Challenges Proposal Competition "Building Climate Resilience: Seeking Sustainable Solutions for Water, Agriculture and Biodiversity in Arid Regions".

Conflicts of Interest: The authors declare no conflict of interest.

\section{References}

1. Zillman, J.W. A history of climate activities. WMO Bull. 2009, 58, 141.

2. Ricketts, T.H.; Dinerstein, E.; Olson, D.M.; Loucks, C.J.; Eichbaum, W.; DellaSala, D.; Kavanagh, K.; Hedao, P.; Hurley, P.T.; Carney, K.M.; et al. Terrestrial Ecoregions of North America: A Conservation Assessment; Island Press: Washington, DC, USA, 1999.

3. Schmidly, D.J. Texas Natural History: A Century of Change; Texas Tech University Press: Lubbock, TX, USA, 2002.

4. U.S. Environmental Protection Agency. What Climate Change Means for Texas. Available online: https://www. epa.gov/sites/production/files/2016-09/documents/climate-change-tx.pdf (accessed on 25 September 2019).

5. U.S. Environmental Protection Agency. Climate Change Indicators: Heavy Precipitation. Available online: https://www.epa.gov/climate-indicators/climate-change-indicators-heavy-precipitation (accessed on 25 September 2019).

6. Melillo, J.M.; Richmond, T.T.; Yohe, G. Climate change impacts in the United States. Third Natl. Clim. Assess. 2014, 52. [CrossRef]

7. Rittenhouse, C.D.; Pidgeon, A.M.; Albright, T.P.; Culbert, P.D.; Clayton, M.K.; Flather, C.H.; Masek, J.G.; Radeloff, V.C. Land-cover change and avian diversity in the conterminous United States. Conserv. Biol. 2012, 26, 821-829. [CrossRef]

8. Karatayev, A.Y.; Burlakova, L.E.; Miller, T.D.; Perrelli, M.F. Reconstructing historical range and population size of an endangered mollusc: Long-term decline of Popenaias popeii in the Rio Grande, Texas. Hydrobiologia 2018, 810, 333-349. [CrossRef] 
9. Flockhart, D.T.T.; Pichancourt, J.B.; Norris, D.R.; Martin, T.G. Unravelling the annual cycle in a migratory animal: Breeding-season habitat loss drives population declines of monarch butterflies. J. Anim. Ecol. 2015, 84, 155-165. [CrossRef] [PubMed]

10. Diffenbaugh, N.S.; Stone, D.A.; Thorne, P.; Giorgi, F.; Hewitson, B.C.; Jones, R.G.; van Oldenborgh, G.J. 2014: Cross-chapter box on the regional climate summary figures. In Climate Change 2014: Impacts, Adaptation, and Vulnerability. Part A: Global and Sectoral Aspects. Contribution of Working Group II to the Fifth Assessment Report of the Intergovernmental Panel on Climate Change; Field, C.B., Barros, V.R., Dokken, D.J., Mach, K.J., Mastrandrea, M.D., Bilir, T.E., Chatterjee, M., Ebi, K.L., Estrada, Y.O., Genova, R.C., et al., Eds.; Cambridge University Press: Cambridge, UK; New York, NY, USA, 2014; pp. 137-141.

11. Wuebbles, D.J.; Kunkel, K.; Wehner, M.; Zobel, Z. Severe weather in the United States under a changing climate. Eos Trans. AGU 2014, 95, 149-150. [CrossRef]

12. Shafer, M.; Ojima, D.; Antle, J.M.; Kluck, D.; McPherson, R.A.; Petersen, S.; Scanlon, B.; Sherman, K. Great Plains. In Climate Change Impacts in the United States: The Third National Climate Assessment; Melillo, J.M., Richmond, T., Yohe, G.W., Eds.; USA Global Change Research Program: Washington, DC, USA, 2014; pp. 441-461. [CrossRef]

13. Williams, J.W.; Jackson, S.T.; Kutzbach, J.E. Projected distributions of novel and disappearing climates by 2100 AD. Proc. Natl. Acad. Sci. USA 2007, 104, 5738-5742. [CrossRef] [PubMed]

14. Kardol, P.; Reynolds, W.N.; Norby, R.J.; Classen, A.T. Climate change effects on soil microarthropod abundance and community structure. Appl. Soil Ecol. 2011, 47, 37-44. [CrossRef]

15. Chen, C.C.; McCarl, B.A. Hurricanes and Possible Intensity Increases: Effects on and Reactions From US Agriculture. Am. J. Agric. Econ. 2009, 41, 125-144. [CrossRef]

16. Schlenker, W.; Roberts, M.J. Nonlinear temperature effects indicate severe damages to U.S. crop yields under climate change. Proc. Natl. Acad. Sci. USA 2009, 106, 15594-15598. [CrossRef]

17. Lobell, D.B.; Hammer, G.L.; McLean, G.; Messina, C.; Roberts, M.J.; Schlenker, W. The critical role of extreme heat for maize production in the United States. Nat. Clim. Chang. 2013, 3, 497-501. [CrossRef]

18. Lobell, D.B.; Schlenker, W.; Costa-Roberts, J. Climate trends and global crop production since 1980. Science 2011, 333, 616-620. [CrossRef] [PubMed]

19. Cho, S.J.; McCarl, B.A. Climate change influences on crop mix shifts in the United States. Sci. Rep. 2017, 7, 40845. [CrossRef] [PubMed]

20. Camara, K.M.; Payne, W.A.; Rasmussen, P.E. Long-term effects of tillage, nitrogen, and rainfall on winter wheat yields in the Pacific Northwest. Agron. J. 2003, 95, 828-835. [CrossRef]

21. Leakey, A.D.; Uribelarrea, M.; Ainsworth, E.A.; Naidu, S.L.; Rogers, A.; Ort, D.R.; Long, S.P. Photosynthesis, productivity, and yield of maize are not affected by open-air elevation of $\mathrm{CO}_{2}$ concentration in the absence of drought. Plant Physiol. 2006, 140, 779-790. [CrossRef] [PubMed]

22. Fei, C.J.; McCarl, B.A.; Thayer, A.W. Estimating the impacts of climate change and potential adaptation strategies on cereal grains in the United States. Front. Ecol. Evol. 2017, 5, 62. [CrossRef]

23. McCarl, B.A.; Villavicencio, X.; Wu, X. Climate change and future analysis: Is stationarity dying? Am. J. Agric. Econ. 2008, 90, 1241-1247. [CrossRef]

24. Long, S.P.; Ainsworth, E.A.; Leakey, A.D.; Nösberger, J.; Ort, D.R. Food for thought: Lower-than-expected crop yield stimulation with rising $\mathrm{CO}_{2}$ concentrations. Science 2006, 312, 1918-1921. [CrossRef]

25. Attavanich, W.; McCarl, B.A. How is $\mathrm{CO}_{2}$ affecting yields and technological progress? A statistical analysis. Clim. Chang. 2014, 124, 747-762. [CrossRef]

26. Chen, C.C.; Gillig, D.; McCarl, B.A. Effects of climatic change on a water dependent regional economy: A study of the Texas Edwards aquifer. Clim. Chang. 2001, 49, 397-409. [CrossRef]

27. Kapilakanchana, M. The Effect of Technological Progress, Demand, and Energy Policy on Agricultural and Bioenergy Markets. Ph.D. Thesis, Texas A\&M University, College Station, TX, USA, 2016.

28. Chen, C.C.; McCarl, B.A. An investigation of the relationship between pesticide usage and climate change. Clim. Chang. 2001, 50, 475-487. [CrossRef]

29. Wang, Z. Three Essays on Climate Change, Renewable Energy, and Agriculture in the US. Ph.D. Thesis, Texas A\&M University, College Station, TX, USA, 2018.

30. Steiner, J.L.; Briske, D.D.; Brown, D.P.; Rottler, C.M. Vulnerability of Southern Plains agriculture to climate change. Clim. Chang. 2018, 146, 201-218. [CrossRef] 
31. Cook, B.I.; Ault, T.R.; Smerdon, J.E. Unprecedented 21st century drought risk in the American Southwest and Central Plains. Sci. Adv. 2015, 1, e1400082. [CrossRef] [PubMed]

32. Walthall, C.L.; Hatfield, J.; Backlund, P.; Lengnick, L.; Marshall, E.; Walsh, M.; Adkins, S.; Aillery, M.; Ainsworth, E.A.; Ammann, C.; et al. Climate Change and Agriculture in the United States: Effects and Adaptation; Technical Bulletin 1935; U.S. Department of Agriculture: Washington, DC, USA, 2012.

33. Rötter, R.; Van de Geijn, S.C. Climate change effects on plant growth, crop yield and livestock. Clim. Chang. 1999, 43, 651-681. [CrossRef]

34. St. Pierre, N.R.; Cobanov, B.; Schnitkey, G. Economic losses from heat stress by US livestock industries. J. Dairy Sci. 2003, 86, E52-E77. [CrossRef]

35. Ferreira, F.C.; Gennari, R.S.; Dahl, G.E.; De Vries, A. Economic feasibility of cooling dry cows across the United States. J. Dairy Sci. 2016, 99, 9931-9941. [CrossRef]

36. Yu, C.H.; Park, S.C.; McCarl, B.; Amosson, S.H. Feedlots, Air Quality and Dust Control-Benefit Estimation under Climate Change. In 2012 Annual Meeting, August 12-14, 2012, Seattle, Washington (No. 124736); Agricultural and Applied Economics Association: Milwaukee, WI, USA, 2012.

37. Yu, C.H. Case Studies on the Effects of Climate Change on Water, Livestock and Hurricanes. Ph.D. Thesis, Texas A\&M University, College Station, TX, USA, 2014.

38. Derner, J.; Briske, D.; Reeves, M.; Brown-Brandl, T.; Meehan, M.; Blumenthal, D.; Travis, W.; Augustine, D.; Wilmer, H.; Scasta, D.; et al. Vulnerability of grazing and confined livestock in the Northern Great Plains to projected mid-and late-twenty-first century climate. Clim. Chang. 2018, 146, 19-32. [CrossRef]

39. Craine, J.M.; Elmore, A.; Angerer, J.P. Long-term declines in dietary nutritional quality for North American cattle. Environ. Res. Lett. 2017, 12, 044019. [CrossRef]

40. Briske, D.D.; Joyce, L.A.; Polley, H.W.; Brown, J.R.; Wolter, K.; Morgan, J.A.; McCarl, B.A.; Bailey, D.W. Climate-change adaptation on rangelands: Linking regional exposure with diverse adaptive capacity. Front. Ecol. Environ. 2015, 13, 249-256. [CrossRef]

41. Mu, J.E.; McCarl, B.A.; Wein, A.M. Adaptation to climate change: Changes in farmland use and stocking rate in the USA. Mitig. Adapt. Strateg. Glob. Chang. 2013, 18, 713-730. [CrossRef]

42. Porter, J.R.; Xie, L.; Challinor, A.J.; Cochrane, K.; Howden, S.M.; Iqbal, M.M.; Lobell, D.B.; Travasso, M.I. Food security and food production systems. In Climate Change 2014: Impacts, Adaptation, and Vulnerability. Part A: Global and Sectoral Aspects. Contribution of Working Group II to the Fifth Assessment Report of the Intergovernmental Panel on Climate Change; Field, C.B., Barros, V.R., Dokken, D.J., Mach, K.J., Mastrandrea, M.D., Bilir, T.E., Chatterjee, M., Ebi, K.L., Estrada, Y.O., Genova, R.C., et al., Eds.; Cambridge University Press: Cambridge UK; New York, NY, USA, 2014; pp. 485-533.

43. Antle, J.M.; Capalbo, S.M. Adaptation of agricultural and food systems to climate change: An economic and policy perspective. Appl. Econ. Perspect. Policy 2010, 32, 386-416. [CrossRef]

44. Schmidhuber, J.; Tubiello, F.N. Global food security under climate change. Proc. Natl. Acad. Sci. USA 2007, 104, 19703-19708. [CrossRef] [PubMed]

45. Attavanich, W.; McCarl, B.A.; Ahmedov, Z.; Fuller, S.W.; Vedenov, D.V. Effects of climate change on US grain transport. Nat. Clim. Chang. 2013, 3, 638. [CrossRef]

46. Butt, T.A.; McCarl, B.A.; Angerer, J.; Dyke, P.T.; Stuth, J.W. The economic and food security implications of climate change in Mali. Clim. Chang. 2005, 68, 355-378. [CrossRef]

47. Ahmed, S.A.; Diffenbaugh, N.S.; Hertel, T.W. Climate volatility deepens poverty vulnerability in developing countries. Environ. Res. Lett. 2009, 4, 034004. [CrossRef]

48. McCarl, B.A.; Hertel, T.W. Climate change as an agricultural economics research topic. Appl. Econ. Perspect. Policy 2018, 40, 60-78. [CrossRef]

49. Kjellstrom, T.; Kovats, R.S.; Lloyd, S.J.; Holt, T.; Tol, R.S.J. The direct impact of climate change on regional labor productivity. Arc. Environ. Occup. Health 2009, 64, 217-227. [CrossRef]

50. Hertel, T.W.; Rosch, S.D. Climate Change, Agriculture and Poverty; Policy Working Paper; The World Bank: Washington, DC, USA, 2010.

51. Parmesan, C.; Yohe, G. A globally coherent fingerprint of climate change impacts across natural systems. Nature 2003, 421, 37-42. [CrossRef]

52. Lawing, A.M.; Polly, P.D.; Hews, D.K.; Martins, E.P. Including fossils in phylogenetic climate reconstructions: A deep time perspective on the climatic niche evolution and diversification of spiny lizards (Sceloporus). Am. Nat. 2016, 188, 133-148. [CrossRef] 
53. Bellard, C.; Bertelsmeier, C.; Leadley, P.; Thuiller, W.; Courchamp, F. Impacts of climate change on the future of biodiversity: Biodiversity and climate change. Ecol. Lett. 2012, 15, 365-377. [CrossRef]

54. Urban, M.C.; Bocedi, G.; Hendry, A.P.; Mihoub, J.B.; Peer, G.; Singer, A.; Bridle, J.R.; Crozier, L.G.; De Meester, L.; Godsoe, W.; et al. Improving the forecast for biodiversity under climate change. Science 2016, 353, aad8466. [CrossRef] [PubMed]

55. Anderson, R.P. Harnessing the world's biodiversity data: Promise and peril in ecological niche modeling of species distributions. Ann. N. Y. Acad. Sci. 2012, 1260, 66-80. [CrossRef] [PubMed]

56. Amatulli, G.; Domisch, S.; Tuanmu, M.N.; Parmentier, B.; Ranipeta, A.; Malczyk, J.; Jetz, W. A suite of global, cross-scale topographic variables for environmental and biodiversity modeling. Sci. Data 2018, 5, 180040. [CrossRef] [PubMed]

57. Fick, S.E.; Hijmans, R.J. WorldClim 2: New 1-km spatial resolution climate surfaces for global land areas. Int. J. Climatol. 2017, 37, 4302-4315. [CrossRef]

58. Hengl, T.; de Jesus, J.M.; Heuvelink, G.B.; Gonzalez, M.R.; Kilibarda, M.; Blagotić, A.; Shangguan, W.; Wright, M.N.; Geng, X.; Bauer-Marschallinger, B.; et al. SoilGrids250 m: Global gridded soil information based on machine learning. PLoS ONE 2017, 12, e0169748. [CrossRef]

59. Harris, R.M.; Grose, M.R.; Lee, G.; Bindoff, N.L.; Porfirio, L.L.; Fox-Hughes, P. Climate projections for ecologists. Wiley Interdiscip. Rev. Clim. Chang. 2014, 5, 621-637. [CrossRef]

60. Bagchi, R.; Hole, D.G.; Butchart, S.H.M.; Collingham, Y.C.; Fishpool, L.D.; Plumptre, A.J.; Owiunji, I.; Mugabe, H.; Willis, S.G. Forecasting potential routes for movement of endemic birds among important sites for biodiversity in the Albertine Rift under projected climate change. Ecography 2018, 41, 401-413. [CrossRef]

61. Thomas, C.D.; Franco, A.M.; Hill, J.K. Range retractions and extinction in the face of climate warming. Trends Ecol. Evol. 2006, 21, 415-416. [CrossRef]

62. Telwala, Y.; Brook, B.W.; Manish, K.; Pandit, M.K. Climate-induced elevational range shifts and increase in plant species richness in a Himalayan biodiversity epicentre. PLoS ONE 2013, 8, e57103. [CrossRef]

63. Bell, D.M.; Bradford, J.B.; Lauenroth, W.K. Early indicators of change: Divergent climate envelopes between tree life stages imply range shifts in the western United States: Early indications of tree range shift. Glob. Ecol. Biogeogr. 2014, 23, 168-180. [CrossRef]

64. Freeman, B.G.; Freeman, A.M.C. Rapid upslope shifts in New Guinean birds illustrate strong distributional responses of tropical montane species to global warming. Proc. Natl. Acad. Sci. USA 2014, 111, 4490-4494. [CrossRef] [PubMed]

65. Röpke, C.P.; Amadio, S.; Zuanon, J.; Ferreira, E.J.G.; de Deus, C.P.; Pires, T.H.S.; Winemiller, K.O. Simultaneous abrupt shifts in hydrology and fish assemblage structure in a floodplain lake in the central Amazon. Sci. Rep. 2017, 7, 40170. [CrossRef] [PubMed]

66. Moritz, C.; Patton, J.L.; Conroy, C.J.; Parra, J.L.; White, G.C.; Beissinger, S.R. Impact of a century of climate change on small-mammal communities in Yosemite National Park, USA. Science 2008, 322, 261-264. [CrossRef] [PubMed]

67. Sgrò, C.M.; Lowe, A.J.; Hoffmann, A.A. Building evolutionary resilience for conserving biodiversity under climate change: Conserving biodiversity under climate change. Evol. Appl. 2011, 4, 326-337. [CrossRef]

68. Foster, C.R.; Amos, A.F.; Fuiman, L.A. Phenology of six migratory coastal birds in relation to climate change. Wilson J. Ornithol. 2010, 122, 116-125. [CrossRef]

69. Cameron, G.N.; Scheel, D. Getting warmer: Effect of global climate change on distribution of rodents in Texas. J. Mammal. 2001, 82, 652-680. [CrossRef]

70. Dantas-Torres, F.; Chomel, B.B.; Otranto, D. Ticks and tick-borne diseases: A One Health perspective. Trends Parasitol. 2012, 28, 437-446. [CrossRef]

71. Feria-Arroyo, T.P.; Castro-Arellano, I.; Gordillo-Perez, G.; Cavazos, A.L.; Vargas-Sandoval, M.; Grover, A.; Torres, J.; Medina, R.F.; Pérez de León, A.A.; Esteve-Gassent, M.D. Implications of climate change on the distribution of the tick vector Ixodes scapularis and risk for Lyme disease in the Texas-Mexico transboundary region. Parasit. Vectors 2014, 7, 199. [CrossRef]

72. Pérez de León, A.A.; Teel, P.D.; Auclair, A.N.; Messenger, M.T.; Guerrero, F.D.; Schuster, G.; Miller, R.J. Integrated strategy for sustainable cattle fever tick eradication in USA is required to mitigate the impact of global change. Front. Physiol. 2012, 3, 195. [CrossRef] 
73. Castellanos, A.A.; Medeiros, M.C.I.; Hamer, G.L.; Teel, P.D.; Hamer, S.A.; Eubanks, M.D.; Morrow, M.E.; Light, J.E. Decreased small mammal and on-host tick abundance in association with invasive red imported fire ants (Solenopsis invicta). Biol. Lett. 2016, 12, 20160463. [CrossRef]

74. Grime, J.P. Evidence for the existence of three primary strategies in plants and its relevance to ecological and evolutionary theory. Am. Nat. 1977, 111, 1169-1194. [CrossRef]

75. Huston, M.A. Biological Diversity: The Coexistence of Species; Cambridge University Press: Cambridge, UK, 1994.

76. Allen, C.D.; Macalady, A.K.; Chenchouni, H.; Bachelet, D.; McDowell, N.; Vennetier, M.; Kitzberger, T.; Rigling, A.; Breshears, D.D.; Hogg, E.H.; et al. A global overview of drought and heat-induced tree mortality reveals emerging climate change risks for forests. For. Ecol. Manag. 2010, 259, 660-684. [CrossRef]

77. Aragón-Gastélum, J.L.; Flores, J.; Yáñez-Espinosa, L.; Badano, E.; Ramírez-Tobías, H.M.; Rodas-Ortíz, J.P.; González-Salvatierra, C. Induced climate change impairs photosynthetic performance in Echinocactus platyacanthus, an especially protected Mexican cactus species. Flora-Morphol. Distrib. Funct. Ecol. Plants 2014, 209, 499-503. [CrossRef]

78. Islam, A.; Ahuja, L.R.; Garcia, L.A.; Ma, L.; Saseendran, A.S. Modeling the effect of elevated $\mathrm{CO}_{2}$ and climate change on reference evapotranspiration in the semi-arid Central Great Plains. Trans. ASABE 2012, 55, 2135-2146. [CrossRef]

79. Hernandez, E.A.; Uddameri, V. Standardized precipitation evaporation index (SPEI)-based drought assessment in semi-arid South Texas. Environ. Earth Sci. 2014, 71, 2491-2501. [CrossRef]

80. Heisler-White, J.L.; Blair, J.M.; Kelly, E.F.; Harmoney, K.; Knapp, A.K. Contingent productivity responses to more extreme rainfall regimes across a grassland biome. Glob. Chang. Biol. 2009, 15, 2894-2904. [CrossRef]

81. Serra-Diaz, J.M.; Maxwell, C.; Lucash, M.S.; Scheller, R.M.; Laflower, D.M.; Miller, A.D.; Tepley, A.J.; Epstein, H.E.; Anderson-Teixeira, K.J.; Thompson, J.R. Disequilibrium of fire-prone forests sets the stage for a rapid decline in conifer dominance during the 21st century. Sci. Rep. 2018, 8, 6749. [CrossRef]

82. Young, A.M.; Higuera, P.E.; Duffy, P.A.; Hu, F.S. Climatic thresholds shape northern high-latitude fire regimes and imply vulnerability to future climate change. Ecography 2017, 40, 606-617. [CrossRef]

83. Allen, C.D.; Breshears, D.D. Drought-induced shift of a forest-woodland ecotone: Rapid landscape response to climate variation. Proc. Natl. Acad. Sci. USA 1998, 95, 14839-14842. [CrossRef]

84. Breshears, D.D.; Cobb, N.S.; Rich, P.M.; Price, K.P.; Allen, C.D.; Balice, R.G.; Romme, W.H.; Kastens, J.H.; Floyd, M.L.; Belnap, J.; et al. Regional vegetation die-off in response to global-change-type drought. Proc. Natl. Acad. Sci. USA 2005, 102, 15144-15148. [CrossRef]

85. Richter, B.D. Ecologically sustainable water management: Managing river flows for ecological integrity. Ecol. Appl. 2003, 13, 206-224. [CrossRef]

86. Perkin, J.S.; Gido, K.B.; Costigan, K.H.; Daniels, M.D.; Johnson, E.R. Fragmentation and drying ratchet down Great Plains stream fish diversity. Aquat. Conserv. Mar. Freshw. Ecosyst. 2015, 25, 639-655. [CrossRef]

87. Postel, S.; Carpenter, S. Freshwater ecosystem services. In Nature's Services: Societal Dependence on Natural Ecosystems; Daily, G.C., Ed.; Island Press: Washington, DC, USA, 1997; pp. 195-214. ISBN 9781559634762.

88. Durham, B.W.; Wilde, G.R. Influence of stream discharge on reproductive success of a prairie stream fish assemblage. Trans. Am. Fish Soc. 2006, 135, 1644-1653. [CrossRef]

89. Rypel, A.L.; Haag, W.R.; Findlay, R.H. Pervasive hydrologic effects on freshwater mussels and riparian trees in southeastern floodplain ecosystems. Wetlands 2009, 29, 497-504. [CrossRef]

90. Roach, K.A. Texas water wars: How politics and scientific uncertainty influence environmental flow decision-making in the Lone Star state. Biodivers. Conserv. 2013, 22, 545-565. [CrossRef]

91. Roelke, D.L.; Brooks, B.W.; Grover, J.P.; Gable, G.M.; Schwierzke-Wade, L.; Hewitt, N.C. Anticipated human population and climate change effects on algal blooms of a toxic haptophyte in the south-central USA. Can. J. Fish. Aquat. Sci. 2012, 69, 1389-1404. [CrossRef]

92. Roelke, D.L.; Barkoh, A.; Brooks, B.W.; Grover, J.P.; Hambright, K.D.; La Claire, J.W., II; Moeller, P.D.R.; Patino, R. A chronicle of a killer alga in the west: Ecology, assessment and management of Prymnesium parvum blooms. Hydrobiologia 2016, 764, 29-50. [CrossRef]

93. Schriever, C.A.; Liess, M. Mapping ecological risk of agricultural pesticide runoff. Sci. Total Environ. 2007, 384, 264-279. [CrossRef]

94. Fulton, M.H.; Moore, D.W.; Wirth, E.F.; Chandler, G.T.; Key, P.B.; Daugomah, J.W.; Strozier, E.D.; Devane, J.; Clark, J.R.; Lewis, M.A.; et al. Assessment of risk reduction strategies for the management of agricultural nonpoint source pesticide runoff in estuarine ecosystems. Toxicol. Ind. Health 1999, 15, 201-214. [CrossRef] 
95. Derner, J.D.; Johnson, H.B.; Kimball, B.A.; Pinter, P.J.; Polley, H.W.; Tischler, C.R.; Boutton, T.W.; LaMorte, R.L.; Wall, G.W.; Adam, N.R.; et al. Above-and below-ground responses of C3-C4 species mixtures to elevated $\mathrm{CO}_{2}$ and soil water availability. Glob. Chang. Biol. 2003, 9, 452-460. [CrossRef]

96. Power, A.G. Ecosystem services and agriculture: Tradeoffs and synergies. Philos. Trans. R. Soc. B Biol. Sci. 2010, 365, 2959-2971. [CrossRef] [PubMed]

97. Nelson, E.; Mendoza, G.; Regetz, J.; Polasky, S.; Tallis, H.; Cameron, D.R.; Chan, K.M.; Daily, G.C.; Goldstein, J.; Kareiva, P.M.; et al. Modeling multiple ecosystem services, biodiversity conservation, commodity production, and tradeoffs at landscape scales. Front. Ecol. Environ. 2009, 7, 4-11. [CrossRef]

98. Sandhu, H.S.; Wratten, S.D.; Cullen, R. From poachers to gamekeepers: Perceptions of farmers towards ecosystem services on arable farmland. Int. J. Agric. Sustain. 2007, 5, 39-50. [CrossRef]

99. Costanza, R.; d'Arge, R.; De Groot, R.; Farber, S.; Grasso, M.; Hannon, B.; Limburg, K.; Naeem, S.; O’Neill, R.V.; Paruelo, J.; et al. The value of the world's ecosystem services and natural capital. Nature 1997, 387, 253-260. [CrossRef]

100. Benton, T.G. Managing farming's footprint on biodiversity. Science 2007, 315, 341-342. [CrossRef]

101. Tsiafouli, M.A.; Thébault, E.; Sgardelis, S.P.; De Ruiter, P.C.; Van Der Putten, W.H.; Birkhofer, K.; Hemerik, L.; De Vries, F.T.; Bardgett, R.D.; Brady, M.V.; et al. Intensive agriculture reduces soil biodiversity across Europe. Glob. Chang. Biol. 2015, 21, 973-985. [CrossRef]

102. Dale, V.H.; Polasky, S. Measures of the effects of agricultural practices on ecosystem services. Ecol. Econ. 2007, 64, 286-296. [CrossRef]

103. Sandhu, H.S.; Wratten, S.D.; Cullen, R. Organic agriculture and ecosystem services. Environ. Sci. Policy 2010, 13, 1-7. [CrossRef]

104. U.S. Environmental Protection Agency. Climate Change Adaptation Plan. Available online: https://www.epa. gov/sites/production/files/2015-08/documents/adaptationplans2014_508.pdf (accessed on 25 September 2019).

105. Zhang, Y.W.; Hagerman, A.D.; McCarl, B.A. Influence of Climate Factors on Spatial Distribution of Texas Cattle Breeds. Clim. Chang. 2013, 118, 183-195. [CrossRef]

106. Torell, L.A.; Murugan, S.; Ramirez, O.A. Economics of flexible versus conservative stocking strategies to manage climate variability risk. Rangel. Ecol. Manag. 2010, 63, 415-425. [CrossRef]

107. Colby, B.G. Economic impacts of water law-State law and water market development in the southwest. Nat. Resour. J. 1988, 28, 721-749.

108. Falco, S.D.; Adinolfi, F.; Bozzola, M.; Capitanio, F. Crop insurance as a strategy for adapting to climate change. J. Agric. Econ. 2014, 65, 485-504. [CrossRef]

109. Mendelsohn, R. Efficient adaptation to climate change. Clim. Chang. 2000, 45, 583-600. [CrossRef]

110. Hanley, N.; Shogren, J.F.; White, B. Environmental Economics: In Theory an Practice, 2nd ed.; Palgrave Macmillan: New York, NY, USA, 2007; ISBN 978-033-397-137-6.

111. Magnan, A.K.; Schipper, E.L.; Burkett, M.; Bharwani, S.; Burton, I.; Eriksen, S.; Gemenne, F.; Schaar, J.; Ziervogel, G. Addressing the risk of maladaptation to climate change. Wiley Interdiscip. Rev. Clim. Chang. 2016, 7, 646-665. [CrossRef]

112. Butt, T.A.; Mccarl, B.A.; Kergna, A.O. Policies for Reducing Agricultural Sector Vulnerability to Climate Change in Mali. Clim. Policy 2006, 5, 583-598. [CrossRef]

113. Seo, S.N.; McCarl, B.A.; Mendelsohn, R.O. From beef cattle to sheep under global warming? An analysis of adaptation by livestock species choice in South America. Ecol. Econ. 2010, 69, 2486-2494. [CrossRef]

114. Zhang, Y.W.; McCarl, B.A.; Jones, J.P.H. An Overview of Mitigation and Adaptation Needs and Strategies for the Livestock Sector. Climate 2017, 5, 95. [CrossRef]

115. Seo, S.N.; Mendelsohn, R.O.; Dinar, A.; Kurukulasuriya, P. Adapting to climate change mosaically: An analysis of African livestock management by agro-ecological zones. BE J. Econ. Anal. Policy 2009, 9. [CrossRef]

116. Fuhlendorf, S.D.; Engle, D.M. Restoring heterogeneity on rangelands: Ecosystem management based on evolutionary grazing patterns: We propose a paradigm that enhances heterogeneity instead of homogeneity to promote biological diversity and wildlife habitat on rangelands grazed by livestock. BioScience 2001, 51, 625-632. [CrossRef]

117. Megersa, B.; Markemann, A.; Angassa, A.; Ogutu, J.O.; Piepho, H.P.; Zárate, A.V. Livestock diversification: An adaptive strategy to climate and rangeland ecosystem changes in southern Ethiopia. Hum. Ecol. 2014, 42, 509-520. [CrossRef] 
118. Pequeño-Ledezma, M.; Alanís-Rodríguez, E.; Molina-Guerra, V.M.; Mora-Olivo, A.; Alcalá-Rojas, A.G.; Martínez-Ávalos, J.G.; Garza-Ocañas, F. Plant composition and structure of two post-livestock areas of Tamaulipan thornscrub, Mexico. Rev. Chil. Hist. Natl. 2018, 91, 4. [CrossRef]

119. Joyce, L.A.; Briske, D.D.; Brown, J.R.; Polley, H.W.; McCarl, B.A.; Bailey, D.W. Climate change and North American rangelands: Assessment of mitigation and adaptation strategies. Rangel. Ecol. Manag. 2013, 66, 512-528. [CrossRef]

120. Derner, J.D.; Boutton, T.W.; Briske, D.D. Grazing and ecosystem carbon storage in the North American Great Plains. Plant Soil 2006, 280, 77-90. [CrossRef]

121. Derner, J.D.; Schuman, G.E. Carbon sequestration and rangelands: A synthesis of land management and precipitation effects. J. Soil Water Conserv. 2007, 62, 77-85.

122. Rocha, J.F.; Martínez, R.; López-Villalobos, N.; Morris, S.T. Tick burden in Bos taurus cattle and its relationship with heat stress in three agroecological zones in the tropics of Colombia. Parasites Vectors 2019, 12, 73. [CrossRef]

123. Nyamushamba, G.B.; Mapiye, C.; Tada, O.; Halimani, T.E.; Muchenje, V. Conservation of indigenous cattle genetic resources in Southern Africa's smallholder areas: Turning threats into opportunities-A review. Asian Australas. J. Anim. Sci. 2017, 30, 603. [CrossRef]

124. Adams, R.; McCarl, B.; Segerson, K.; Rosenzweig, C.; Bryant, K.; Dixon, B.; Conner, R.; Evenson, R.; Ojima, D. The economic effect of climate change on US agriculture. In The Economic Impact of Climate Change on the United States Economy; Mendelsohn, R., Neumann, J., Eds.; Cambridge University Press: Cambridge, UK, 1999.

125. Chen, C.C.; McCarl, B.A.; Chang, C.C. Climate Change, Sea Level Rise and Rice: Global Market Implications. Clim. Chang. 2012, 110, 543-560. [CrossRef]

126. Karlen, D.L.; Cambardella, C.A.; Kovar, J.L.; Colvin, T.S. Soil quality response to long-term tillage and crop rotation practices. Soil Till. Res. 2013, 133, 54-64. [CrossRef]

127. Page, K.; Dang, Y.; Dalal, R. Impacts of conservation tillage on soil quality, including soil-borne crop diseases, with a focus on semi-arid grain cropping systems. Australas. Plant Pathol. 2013, 42, 363-377. [CrossRef]

128. Barbet-Massin, M.; Thuiller, W.; Jiguet, F. The fate of European breeding birds under climate, land-use and dispersal scenarios. Glob. Chang. Biol. 2012, 18, 881-890. [CrossRef]

129. Mantyka-Pringle, C.S.; Visconti, P.; Di Marco, M.; Martin, T.G.; Rondinini, C.; Rhodes, J.R. Climate change modifies risk of global biodiversity loss due to land-cover change. Biol. Conserv. 2015, 187, 103-111. [CrossRef]

130. Brosi, B.J.; Briggs, H.M. Single pollinator species losses reduce floral fidelity and plant reproductive function. Proc. Natl. Acad. Sci. USA 2013, 110, 13044-13048. [CrossRef] [PubMed]

131. Allen-Wardell, G.; Bernhardt, P.; Bitner, R.; Burquez, A.; Buchmann, S.; Cane, J.; Cox, P.A.; Dalton, V.; Feinsinger, P.; Ingram, M.; et al. The Potential Consequences of Pollinator Declines on the Conservation of Biodiversity and Stability of Food Crop Yields. Conserv. Biol. 1998, 12, 8-17.

132. Rathcke, B.J.; Jules, E.S. Habitat fragmentation and plant-pollinator interactions. Curr. Sci. 1993, 65, $273-277$.

133. Martin, J.M.; Mead, J.I.; Barboza, P.S. Bison body size and climate change. Ecol. Evol. 2018, 8, 4564-4574. [CrossRef] [PubMed]

134. Torell, G.; Lee, K. Impact of Climate Change on Livestock Returns and Rangeland Ecosystem Sustainability in the Southwest. Agric. Resour. Econ. Rev. 2018, 47, 336-356. [CrossRef]

135. Geruo, A.; Velicogna, I.; Kimball, J.S.; Du, J.; Kim, Y.; Colliander, A.; Njoku, E. Satellite-observed changes in vegetation sensitivities to surface soil moisture and total water storage variations since the 2011 Texas drought. Environ. Res. Lett. 2017, 12, 054006. [CrossRef]

136. Schwantes, A.M.; Swenson, J.J.; González-Roglich, M.; Johnson, D.M.; Domec, J.C.; Jackson, R.B. Measuring canopy loss and climatic thresholds from an extreme drought along a fivefold precipitation gradient across Texas. Glob. Chang. Biol. 2017, 5120-5135. [CrossRef]

137. McDonald, R.I.; Girvetz, E.H. Two Challenges for USA Irrigation Due to Climate Change: Increasing Irrigated Area in Wet States and Increasing Irrigation Rates in Dry States. PLoS ONE 2001, 8, e65589. [CrossRef]

138. Rodríguez-Díaz, J.A.; Weatherhead, E.K.; Knox, J.W.; Camacho, E. Climate change impacts on irrigation water requirements in the Guadalquivir river basin in Spain. Reg. Environ. Chang. 2007, 7, 149-159. [CrossRef]

139. Mainali, K.P.; Warren, D.L.; Dhileepan, K.; McConnachie, A.; Strathie, L.; Hassan, G.; Karki, D.; Shrestha, B.B.; Parmesan, C. Projecting future expansion of invasive species: Comparing and improving methodologies for species distribution modeling. Glob. Chang. Biol. 2015, 21, 4464-4480. [CrossRef] [PubMed] 
140. Burlakova, L.E.; Karatayev, A.Y.; Karatayev, V.A.; May, M.E.; Bennett, D.L.; Cook, M.J. Biogeography and conservation of freshwater mussels (Bivalvia: Unionidae) in Texas: Patterns of diversity and threats. Divers. Distrib. 2011, 17, 393-407. [CrossRef]

141. Wolfe, D.W.; Ziska, L.; Petzoldt, C.; Seaman, A.; Chase, L.; Hayhoe, K. Projected change in climate thresholds in the Northeastern, USA: Implications for crops, pests, livestock, and farmers. Mitig. Adapt. Strateg. Glob. Chang. 2008, 13, 555-575. [CrossRef]

142. Smith, R.G.; Menalled, F.D. Integrated Strategies for Managing Agricultural weeds: Making Cropping Systems Less Susceptible to Weed Colonization and Establishment Department of Land Resources and Environmental Sciences; Montana State University Extension: Bozeman, MT, USA, 2006.

143. Lehikoinen, A.; Jaatinen, K. Delayed autumn migration in northern European waterfowl. J. Ornithol. 2012, 153, 563-570. [CrossRef]

144. Schummer, M.L.; Coluccy, J.M.; Mitchell, M.; Van Den Elsen, L. Long-term trends in weather severity indices for dabbling ducks in eastern North America. Wildl. Soc. Bull. 2017, 41, 615-623. [CrossRef]

145. Rand, P.S.; Hinch, S.G.; Morrison, J.; Foreman, M.G.G.; MacNutt, M.J.; MacDonald, J.S.; Healey, M.C.; Farrell, A.P.; Higgs, D.A. Effects of river discharge, temperature, and future climates on energetics and mortality of adult migrating Fraser River sockeye salmon. Trans. Am. Fish. Soc. 2016, 135, 655-667. [CrossRef]

146. MacFarlane, R.B. Energy dynamics and growth of Chinook salmon (Oncorhynchus tshawytscha) from the Central Valley of California during the estuarine phase and first ocean year. Can. J. Fish. Aquat. Sci. 2010, 67, 1549-1565. [CrossRef]

147. Todd, C.D.; Hughes, S.L.; Marshall, C.T.; MacLean, J.C.; Lonergan, M.E.; Biuw, E.M. Detrimental effects of recent ocean surface warming on growth condition of Atlantic salmon. Glob. Chang. Biol. 2008, 14, 958-970. [CrossRef]

148. Sheridan, J.A.; Bickford, D. Shrinking body size as an ecological response to climate change. Nat. Clim. Chang. 2011, 1, 401. [CrossRef]

149. Jonsson, B.; Jonsson, N. Factors affecting marine production of Atlantic salmon (Salmo salar). Can. J. Fish. Aquat. Sci. 2004, 61, 2369-2383. [CrossRef]

150. Tscharntke, T.; Batáry, P.; Dormann, C.F. Set-aside management: How do succession, sowing patterns and landscape context affect biodiversity? Agric. Ecosyst. Environ. 2011, 143, 37-44. [CrossRef]

151. Palm, C.; Blanco-Canqui, H.; DeClerck, F.; Gatere, L.; Grace, P. Conservation agriculture and ecosystem services: An overview. Agric. Ecosyst. Environ. 2014, 187, 87-105. [CrossRef]

152. Busari, M.A.; Kukal, S.S.; Kaur, A.; Bhatt, R.; Dulazi, A.A. Conservation tillage impacts on soil, crop and the environmentInt. Soil Water Conserv. Res. 2015, 3, 119-129. [CrossRef]

153. Seufert, V.; Ramankutty, N.; Foley, J.A. Comparing the yields of organic and conventional agriculture. Nature 2012, 485, 229. [CrossRef] [PubMed]

154. Gebbers, R.; Adamchuk, V.I. Precision agriculture and food security. Science 2010, 327, 828-831. [CrossRef]

155. Bongiovanni, R.; Lowenberg-DeBoer, J. Precision agriculture and sustainability. Precis. Agric. 2004, 5, 359-387. [CrossRef]

156. Lipper, L.; Thornton, P.; Campbell, B.M.; Baedeker, T.; Braimoh, A.; Bwalya, M.; Caron, P.; Cattaneo, A.; Garrity, D.; Henry, K.; et al. Climate-smart agriculture for food security. Nat. Clim. Chang. 2014, 4, 1068-1072. [CrossRef]

157. Campbell, B.; Thornton, P.; Zougmore, D.; van Asten, P.; Lipper, L. Sustainable intensification: What is its role in climate smart agriculture? Curr. Opin. Environ. Sustain. 2014, 8, 39-43. [CrossRef]

158. Thorpe, A.S.; Barnett, D.T.; Elmendorf, S.C.; Hoekman, D.; Jones, K.D.; Levan, K.E.; Stanish, L.F. Introduction to the sampling designs of the National Ecological Observatory Network Terrestrial Observation System. Ecosphere 2016, 7, e01627. [CrossRef]

159. Trivedi, P.; Delgado-Baquerizo, M.; Anderson, I.C.; Singh, B.K. Response of soil properties and microbial communities to agriculture: Implications for primary productivity and soil health indicators. Front. Plant Sci. 2016, 7, 990. [CrossRef]

160. Baltensperger, A.P.; Huettmann, F. Predicted shifts in small mammal distributions and biodiversity in the altered future environment of Alaska: An open access data and machine learning perspective. PLoS ONE 2018, 13, e0194377. [CrossRef] [PubMed] 
161. Beck, J.; Sieber, A. Is the spatial distribution of mankind's most basic economic traits determined by climate and soil alone? PLoS ONE 2010, 5, e10416. [CrossRef] [PubMed]

162. Davis, A.P.; Gole, T.W.; Baena, S.; Moat, J. The impact of climate change on indigenous Arabica coffee (Coffea arabica): Predicting future trends and identifying priorities. PLoS ONE 2012, 7, e47981. [CrossRef] [PubMed]

163. Curtis-Robles, R.; Wozniak, E.J.; Auckland, L.D.; Hamer, G.L.; Hamer, S.A. Combining public health education and disease ecology research: Using citizen science to assess Chagas disease entomological risk in Texas. PLoS Negl. Trop. Dis. 2015, 9, e0004235. [CrossRef]

164. Meierhofer, M.B.; Johnson, J.S.; Leivers, S.J.; Pierce, B.L.; Evans, J.E.; Morrison, M.L. Winter habitats of bats in Texas. PLoS ONE 2019, 14, e0220839. [CrossRef]

165. Ikard, W. Encouraging Conservation in the Lone Star State: How Texas Can Improve Incentives for Landowners to Preserve Private Property from Development. Tex. Envtl. LJ 2008, 39, 147-166.

166. Sorice, M.G.; Haider, W.; Conner, J.R.; Ditton, R.B. Incentive structure of and private landowner participation in an endangered species conservation program. Conserv. Biol. 2011, 25, 587-596. [CrossRef]

167. Kreuter, U.P.; Wolfe, D.W.; Hays, K.B.; Conner, J.R. Conservation credits-Evolution of a market-oriented approach to recovery of species of concern on private land. Rangel. Ecol. Manag. 2017, 70, 264-272. [CrossRef]

168. Agrawal, A. The Role of Local Institutions in Adaptation to Climate Change; World Bank: Washington, DC, USA, 2008. [CrossRef]

169. Marshall, N.A.; Smajgl, A. Understanding variability in adaptive capacity on rangelands. Rangel. Ecol. Manag. 2013, 66, 88-94. [CrossRef]

170. Polasky, S.; Carpenter, S.R.; Folke, C.; Keeler, B. Decision-making under great uncertainty: Environmental management in an era of global change. Trends Ecol. Evol. 2011, 26, 398-404. [CrossRef]

(C) 2020 by the authors. Licensee MDPI, Basel, Switzerland. This article is an open access article distributed under the terms and conditions of the Creative Commons Attribution (CC BY) license (http://creativecommons.org/licenses/by/4.0/). 